\title{
MEASURED RADIATION FIELDS IN COMMERCIAL NUCLEAR POWER PLANTS
}

\author{
J. Ottaviani and D. K. Wehe \\ Department of Nuclear Engineering, University of Michigan, Ann Arbor, MI 48109-2104, U.S.A.
}

(Received 22 April 1988; in revised form 9 September 1988)

\begin{abstract}
This paper presents a compilation of experimental data on radiation fields found in commercial nuclear power plants. Exposure rates for systems and components are described by average values, although these averages may be significantly low (by orders of magnitude) near localized "hot spots". Conditions for, and exposure rates from, important fields are cited for both normal and abnormal operating conditions. Away from hot primary components, exposure rates for both $\gamma$ and neutron fields typically range from 0 to $1000 \mathrm{mrem} \mathrm{h}^{-1}$. Photon fields are most frequently the result of decay from neutron activated materials or fission product deposits. Neutron fields exhibit well-moderated spectra, with few neutrons above 750 $\mathrm{keV}$. There seems to be no correlation between $\gamma$ and neutron fields in a typical nuclear power plant outside the reactor core.
\end{abstract}

\section{INTRODUCTION}

As part of a program to assess the potential for mobile robots in nuclear power plants, a survey was conducted to determine typical neutron and photon radiation fields which could be expected during normal operations, shutdowns and abnormal situations. Because of the difficulty in obtaining this type of information, we have synthesized and integrated data and present it below. While we believe this information to be "representative" for design purposes, the reader is cautioned that the exposures quoted can vary substantially depending on the particular plant, location and situation. As such, these values should be interpreted as "order of magnitude" estimates.

In order to protect plant personnel and electronics from radiation exposure, statements such as: "near steam generators, exposure rates of $X \mathrm{mrad} \mathrm{h}^{-1}$ of $Y \mathrm{eV} \gamma \mathrm{s}$ can be expected" are desired. However, such statements can rarely be made. As yet, the fundamental knowledge of the mechanisms that lead to radiation buildup in power plants has not been applied to these problems, although trends have been observed. In addition, quoted field values frequently do not describe how or precisely where the measurements were made. As a result, the best one can hope for is a range of values and an understanding of the general factors which influence the magnitude and spectrum of the $\gamma$ and neutron radiation fields.

In Section 2 we present a summary of operating and shutdown exposure rates for boiling water reactors (BWRs) and pressurized water reactors (PWRs). In Section 3, the principal factors which influence variations in these field strengths are discussed. In Sections 4 and 5, the $\gamma$ and neutron fields, respectively, are individually addressed. Section 6 examines extreme accident fields. Section 7 summarizes the material presented.

\section{AVERAGE FIELD STRENGTHS}

The assimilated radiation field data are presented in Tables 1-5, and Figs 1-2. All values can be assumed to represent the total combined neutron and $\gamma$ field strengths, except as noted. Table 1 presents a compilation of shutdown and atpower data for selected PWR systems and components. The data are derived from three general sources-studies which compare the accuracy of different detector types, studies which monitor radiation buildup in a few specific components over many plants during shutdown, and new reactor startup test reports. The studies which compare different neutron detector types highlight the difficulty of providing accurate data in intense fields (Rathbun, 1983), but also provide data on the specific components measured. The studies which monitor a few specific components show large variations between measured radiation fields at identical positions in different plants, but again provide good data on these components. The startup testing reports provide fairly complete mappings of intense, at-power fields, but are expected to represent less accurate data. This data will also not show the effects of radiation buildup normally present at more mature plants.

The at-power data presented in Table 1 show a large range of values. The most intense fields shown are near the vessel head and directly above the vessel. These locations do not benefit from the cylindrical biological shield, and have large neutron components. The reactor coolant pumps also show large neutron and $\gamma$ field intensities. The variation in reported data ranges over an order of magnitude for both the neutron and $\gamma$ fields. The data presented for the reactor coolant piping system also varies by an order of magnitude, with the most intense radiation measured between the reactor coolant pump and steam generator. The intense fields present at the adjacent components may be contributing to this higher value and therefore not reflect radiation being emitted solely from the piping. Steam generator data are shown for both inside and outside the steam generator shielding, and clearly show the benefitial effect of the shield.

Table 2 presents average shutdown PWR field data, taken primary from Beal et al. (1987) in a condensed format. During shutdown, one can expect the majority of the radiation to consist of $\gamma$ fields. The dose rates in Table 2 are thus 
Table 1. PWR system/component dose rates

\begin{tabular}{|c|c|c|}
\hline \multirow[b]{2}{*}{ System/component } & \multicolumn{2}{|c|}{ Dose rate $\left(\right.$ rem $\left.^{-1}\right)$} \\
\hline & Shutdown & Operating \\
\hline \multicolumn{3}{|l|}{ Reactor equipment } \\
\hline \multicolumn{3}{|l|}{ Reactor vessel } \\
\hline Above (during vessel operations) & $0.025-1.4$ & - \\
\hline Keyways (below) & $0.7-200^{1}$ & - \\
\hline Under vessel head & $5-15^{1}$ & $394-1300(\mathrm{n})$ \\
\hline Refueling machine & - & $60(\mathrm{n})-75^{2}$ \\
\hline \multirow{2}{*}{ Operating deck (edge of reactor cavity) } & & $0.6^{\prime}(\gamma)$ \\
\hline & & $5-7.7(\mathrm{n})$ \\
\hline \multicolumn{3}{|l|}{ Main heat transport system } \\
\hline \multirow[t]{2}{*}{ Main coolant pumps } & $0.065-0.360$ & $2-22(\mathrm{n})$ \\
\hline & $0.02-0.270$ & $\begin{array}{r}2-25^{1}(\gamma) \\
2.3^{3}-35^{4}(\gamma)\end{array}$ \\
\hline \multicolumn{3}{|l|}{ Steam generators (internal) } \\
\hline Channel head exposure ranges & $6-24$ & - \\
\hline$<4.5$ EFPY $^{5}$ average & 9 & - \\
\hline$>4.5$ EFPY average & $12-15$ & - \\
\hline At manway and inside & 5.1 & - \\
\hline \multicolumn{3}{|l|}{ Steam generators (external) } \\
\hline Inside bioshield & $0.025-12$ & $3-13.75$ \\
\hline Outside bioshield & 0.11 & $0.16-2.75$ \\
\hline Pressurizer & 0.095 & 5.5 \\
\hline \multicolumn{3}{|l|}{ Residual heat removal system } \\
\hline RHR pumps & 0.1 & 0.050 \\
\hline RHR piping and heat exchanger & 0.065 & 0.065 \\
\hline \multicolumn{3}{|l|}{ Other measured positions } \\
\hline Valves (miscellaneous) & $0.075-1$ & - \\
\hline Spent resin loading area & 2 & $1-20$ \\
\hline Regenerative heat exchanger & $0.5-5$ & - \\
\hline \multicolumn{3}{|c|}{$\begin{array}{l}\text { (Scaglia and Bergmann, 1987; Beal et al., 1987; Bradshaw, 1987; Roberson et al., } 1984 \text {; } \\
\text { White } \text { et al., 1984; VEPCo, 1979; Vance } \text { et al., 1978; Vergnaud, 1984; Uhrig, 1977) }\end{array}$} \\
\hline \multicolumn{3}{|c|}{$\begin{array}{l}{ }^{1} \text { Values listed as rad } h^{-1} \text {. For } \gamma \text { rays, } 1 \mathrm{rad}^{-1} \mathrm{~h}^{-1} \text { is approximately equal to } 1 \mathrm{rem}^{-1} \text {. } \\
2 \text { Value is quoted as } 60 \mathrm{rem} \mathrm{h}^{-1} \text { neutrons. A value of } 75 \mathrm{rem} \mathrm{h}^{-1} \text { total field strength is obtained } \\
\text { by using nearby } \gamma / \text { neutron field intensity ratios. } \\
{ }^{3} \text { Value quoted is rad } h^{-1} \text {. A conversion factor of unity is assumed. } \\
{ }^{4} \text { Measured by contact on pipe between reactor coolant pump and steam generator, and pre- } \\
\text { sented as rad } h^{-1} \text {. } \\
{ }^{5} \text { Plant operating time in units of effective full power years (EFPY). }\end{array}$} \\
\hline
\end{tabular}

averages of typical $\gamma$-field values from several plants and excludes data taken near hot spots. For example, hot spots in reactor coolant piping have yielded $2 \mathrm{rem} \mathrm{h}^{-1}$ shutdown $\gamma$ fields although the expected field strength is an order of magnitude less. The most intense shutdown field reported, up to $200 \mathrm{rem} \mathrm{h}^{-1}$, occurs under the reactor vessel in the keyways.

Table 3 gives broad area averages for PWR containments when the plant is operating at-power, whereas Tables 1 and 2 primarily present data near specific systems or components. In this table, $\gamma$ and neutron contributions are explicitly delineated. Note that these broad area averages are significantly lower than the measured values near the primary components. The area around the reactor cavity includes some spots close to hot primary components, however. The generic category of other levels includes middle and lower levels of containment. Because of the biological shield, the middle level dose values are typically smaller than the operating level. The same is true for the lower level, although to a lesser degree. Figure 1 presents a coherent view of selected data from Tables 1-3 schematically.

Data for BWRs are given in Tables 4 and 5, and Fig. 2. Table 4 presents shutdown and at-power data for selected
BWR systems and components of particular importance to personnel exposure. However, no at-power radiation maps of the drywell were obtained. This may be partially because the drywell is not intended to be habitable during operation, frequently having intense radiation fields (estimated on the order of $10^{2} \mathrm{rem} \mathrm{h}^{-1}$ ) and an inert atmosphere. Except for rather simple instrumentation, most conventional instrumentation packages could not withstand this environment for an extended period. Operating data for outside the drywell were primarily obtained from the Fermi-II BWR.

Tables 4 and 5 present a more complete picture of the shutdown radiation fields at BWRs. As with PWRs, large variations in radiation fields on individual components are seen. For example, values of 0.025 to $1.2 \mathrm{rem} \mathrm{h}^{-1}$ are reported on recirculation line piping, although the average value across several plants was only $0.260 \mathrm{rem} \mathrm{h}^{-1}$. Similarly, the reactor water cleanup ( $R W C U$ ) pump inlet data extend from 0.015 to $2.58 \mathrm{rem} \mathrm{h}^{-1}$, but the average over several plants was $0.375 \mathrm{rem} \mathrm{h}^{-1}$. For the RWCU pump outlet, it is interesting that the operating value quoted for a new plant is less than some shudown values at more mature plants. Possible reasons for this are discussed in Section 3 below. Figure 2 shows a schematic view of selected data from Tables 4 and 5 . 
Table 2. PWR system shutdown dose rates $\left(>25\right.$ mrem $^{-1}$ )

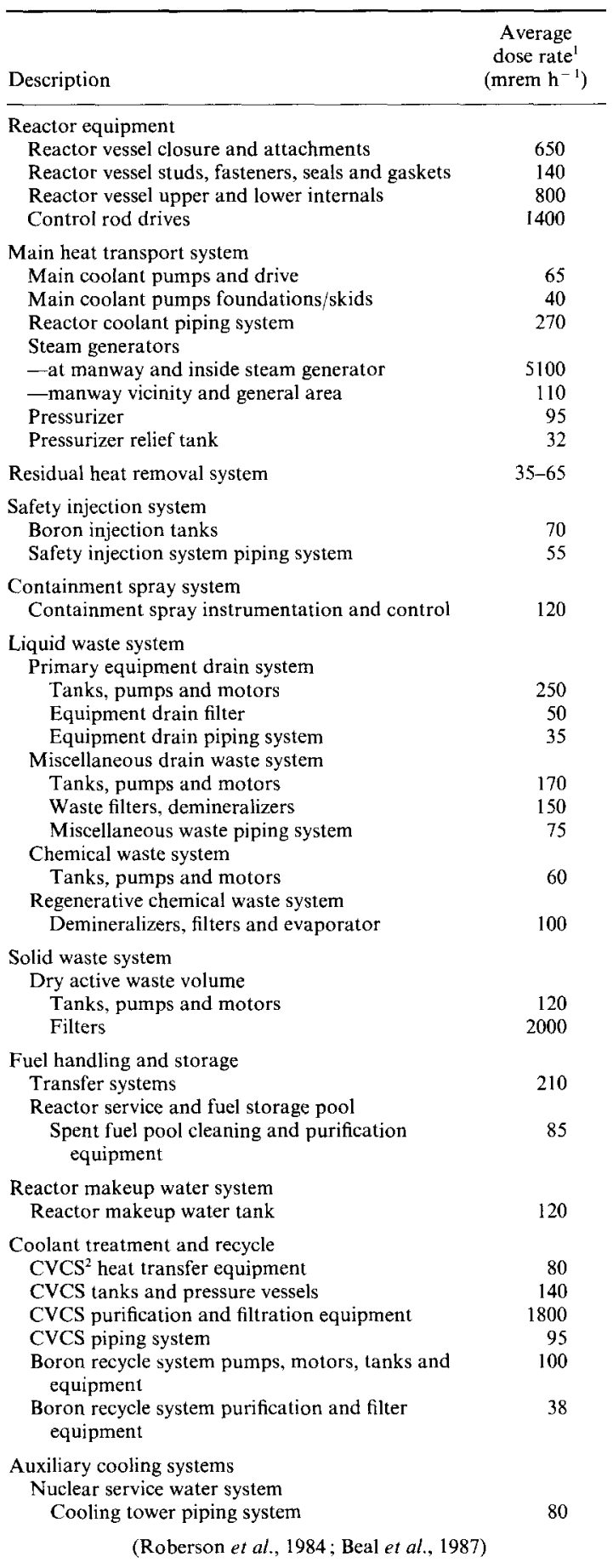

\footnotetext{
'Average of across-plant typical values.
}

${ }^{2}$ Chemical and volume control system.
Table 3. Containment operating dose rates

\begin{tabular}{|c|c|}
\hline Broad area & $\begin{array}{l}\text { Dose rate (mrem } \mathrm{h}^{-1} \text { ) } \\
\text { (range of values) }\end{array}$ \\
\hline \multicolumn{2}{|c|}{ Operating level, general area } \\
\hline $\begin{array}{l}\gamma \\
\mathrm{n}\end{array}$ & $\begin{aligned} 75 & (15-500) \\
530 & (3-2200)\end{aligned}$ \\
\hline \multicolumn{2}{|c|}{ Operating level, around reactor cavity } \\
\hline$\gamma$ & $\begin{aligned} 400 & (20-2000) \\
2600 & (90-12,500)\end{aligned}$ \\
\hline \multicolumn{2}{|c|}{ Other levels, general area } \\
\hline $\begin{array}{l}\gamma \\
\text { n }\end{array}$ & $\begin{array}{l}17(3-500) \\
11(8-200)\end{array}$ \\
\hline \multicolumn{2}{|c|}{ Other levels, around reactor cavity } \\
\hline $\begin{array}{l}\gamma \\
\mathrm{n}\end{array}$ & $\begin{array}{l}100(36-4000) \\
310(90-6000)\end{array}$ \\
\hline \multicolumn{2}{|c|}{$\begin{array}{c}\text { (Ryan, 1983; Endres et al, } 1981 \text {; Uhrig, 1977; SMUD, 1975; } \\
\text { Champion et al., 1984) }\end{array}$} \\
\hline
\end{tabular}

\section{PRINCIPAL FACTORS AFFECTING FIELD STRENGTHS}

In an effort to understand the sources of the wide range of radiation levels measured at identical locations in similar plants, a number of studies have examined the sources of the shutdown radiation fields, and the variables which primarily influence these fields for BWRs and PWRs. Some results from these efforts are presented below.

For BWRs, reactor water quality, ${ }^{60} \mathrm{Co}$ and feedwater iron contamination play significant roles in the radiation buildup in BWR primary piping (Anstine, 1983). In fact, BWR drywell radiation fields are determined principally by primary piping system radioactivity. BWR hot spots have been found to develop from the accumulation of corrosion products (Earls and Blok, 1986).

Although the size of the reactor water cleanup (RWCU) system and the type of condensate treatment demineralizers do not correlate to radiation buildup, the exposure rates in the RWCU system are usually higher than in the recirculation lines because of the hot spots formed by crud deposition in low flow areas. Recirculation lines are both a major source of drywell exposure and are geometrically similar from plant to plant. However, exposure rates on BWR recirculation lines do not necessarily reflect buildup throughout the primary system (Anstine, 1983).

For PWRs, the buildup of fields outside of the core depends on the quantity of corrosion and erosion products being activated. Thus, similar to BWRs, preventing field formation requires the elimination of corrosion and/or prevention of corrosion product deposition in systems external to the core (Burg et al., 1980, Scaglia and Bergmann, 1987). One other interesting insight regarding PWR exposures is that exposure rates outside of PWR steam generators (one of the main sources of personnel exposure in PWRs) do not necessarily correlate to those found inside the steam generator channel head.

A number of additional factors beyond the specific component surveyed or level of corrosion present influence the measured radiation fields, and thus the accuracy and spread of the measured radiation fields. These include:

1. Shutdown vs operating condition (including percentage of full power), as well as time after shutdown and effective full power years (EFPYs) of reactor operation. However, operating floor dose rates are relatively uniform at each 
Table 4. BWR system/component dose rates

\begin{tabular}{|c|c|c|}
\hline \multirow[b]{2}{*}{ System/component } & \multicolumn{2}{|c|}{ Dose rate $\left(r e m h^{-1}\right)$} \\
\hline & Shutdown & Operating \\
\hline \multicolumn{3}{|l|}{ Reactor equipment } \\
\hline Reactor vessel operations & $0.04-0.30$ & \\
\hline Control rod drives & $0.11-0.26$ & \\
\hline \multicolumn{3}{|l|}{ Main heat transport system } \\
\hline Recirculation line & $0.025-1.2$ & - \\
\hline Main steam line & $0.002-0.250$ & $3-8$ \\
\hline Main stream isolation valve & 0.075 & $0.4-8$ \\
\hline Feed heater pump & 0.125 & \\
\hline Feed heaters & & $0.8-2$ \\
\hline Feedwater spargers & 0.240 & \\
\hline \multicolumn{3}{|l|}{ Residual heat removal system } \\
\hline RHR heat exchanger & $0.2-0.7$ & 0.1 \\
\hline \multicolumn{3}{|l|}{ Reactor water cleanup system } \\
\hline Pump inlet & $0.015-2.58$ & - \\
\hline Outlet & $0.015-3.04$ & 1.5 \\
\hline Casing & $0.025-2.00$ & \\
\hline Valve & 0.11 & \\
\hline Regenerative heat exchanger & $0.010-2.8$ & 1 \\
\hline Nonregeneative heat exchanger & $0.005-0.260$ & \\
\hline Drain lines from heat exchangers & $3-15$ & 4 \\
\hline Phase separator & & $\leqslant 100$ \\
\hline Turbine building floors & & $0.01-6$ \\
\hline Moisture separator and reheaters & $0.2-2$ & 2 \\
\hline \multicolumn{3}{|l|}{ Waste systems } \\
\hline Spent resin tank & 0.45 & \\
\hline Waste packing room & $0.2-15$ & \\
\hline
\end{tabular}

(Anstine, 1983 ; Beal et al., 1987; Palino et al., 1987; Roberson et al., 1984 ; White et al., 1984; Vance et al., 1978)

power level (Uhrig, 1977). For older plants as a whole, PWR radiation fields level off after $\sim 1$ EFPY and BWR fields after 4 EFPY [Beal et al., 1987; Burg et al., 1980]. Water chemistry has received increased consideration over the last several years, so these two findings may no longer be as generally applicable. Steam generator channel exposures have been seen to level off at $\sim 10-20 \mathrm{rem} \mathrm{h}^{-1}$ after 5-6 EFPY, and even decline slightly thereafter (Scaglia and Bergmann, 1987). Similarly, in BWRs, the high levels found in the recirculation piping system $\left(\sim 800 \mathrm{mrem}\right.$ rad $\left.\mathrm{h}^{-1}\right)$ reach maximum values after 4-5 EFPY (Anstine, 1983).

2. Decontamination of component hot spots nearby. Cases are cited of an order-of-magnitude change in exposure rates over $1 \mathrm{~m}$ of piping (Anstine, 1983; Sejvar et al., 1981).

3. Significant cladding failures.

4. Component wall thickness. Interestingly, PWR steam generator wall thickness has been found not to significantly affect external fields (Scaglia and Bergmann, 1987).

5. Plant elevation. Measurements made on a given component at an elevation corresponding to core midplane are frequently different than those below or above.

6. Coolant levels.

7. Insulation type and thickness.

8. Instrumentation used for the measurement (Scaglia and Bergmann, 1987; Rathbun, 1983).

While these factors have been identified, it has not been possible to quantitatively estimate their impact on the range of measured field strengths.

\section{4. $\gamma$-RAY EXPOSURES}

Once a significant radiation field or hot spot is identified, it is informative to determine its radiation type and spectrum.
Depending on the location, low $(\sim 100-500 \mathrm{keV})$, medium $(\sim 500-1000 \mathrm{keV})$ and $/$ or high $(>1000 \mathrm{keV})$ energy photons can be major contributors to exposure. For example, high energy fields are dominant in PWR containments (e.g. near steam generators) and on BWR turbine floors. In PWRs, radiation under the vessel is primarily from high-energy photons resulting from phenomena related to capture and inelastic scattering of neutrons. In particular, $90 \%$ of these $\gamma$ s have an energy greater than $1 \mathrm{MeV}$ and $60 \%$ have energies greater than $2 \mathrm{MeV}$ (Earls and Blok, 1986). The PWR steam generator channel heads (where photons of up to $8 \mathrm{MeV}$ can be found) represent another primary source of high-energy radiation fields. For BWR turbine floors during operation, high-energy ${ }^{16} \mathrm{~N}$ photons dominate the spectra and contribute up to $80 \%$ of the exposure there. Nevertheless, when comparing plantwide operating vs shutdown conditions, it has been found that no large difference exists in the relative amounts of low- vs high-energy photons (Robertson et al., 1984). This suggests that plant history, especially water chemistry, is a critical factor in the magnitude of the radiation fields encountered.

The major categories of $\gamma$ radiation areas are:

(1) fields dominated by high-energy fission $\gamma \mathrm{s}$;

(2) fields caused by short-lived radioactive noble gases;

(3) fields dominated by decay photons from radioactive atoms in neutron activated or fission product deposits, and by the scattered photon continuum that results from these deposits.

The first category is found only during operation. The third category is the most prevalent for both shutdown and operating reactors. The neutron activated fission product isotopes that normally contribute to the background energy spectrum 
Table 5. BWR system shutdown dose rates $\left(>25 \mathrm{mrem} \mathrm{h}^{-1}\right.$ )

\begin{tabular}{|c|c|}
\hline Description & $\begin{array}{c}\text { Average } \\
\text { dose rate } \\
\left(\text { mrem }^{-1}\right)\end{array}$ \\
\hline \multicolumn{2}{|l|}{ Reactor equipment } \\
\hline $\begin{array}{l}\text { Reactor vessel closure and attachments, studs, fasteners, seals, gaskets, core support } \\
\text { and shroud assembly }\end{array}$ & 40 \\
\hline Jet pump assemblies & 4400 \\
\hline Fluid distribution assemblies & 210 \\
\hline Steam dryer assembly & 800 \\
\hline Control rods & 170 \\
\hline Control rod drives & 110 \\
\hline \multicolumn{2}{|l|}{ Main heat transport system } \\
\hline Reactor recirculation pumps and motors & 90 \\
\hline Recirculation piping system & 240 \\
\hline Reactor recirculation instrumentation and control & 200 \\
\hline \multicolumn{2}{|l|}{ Residual heat removal system } \\
\hline RHR pumps and drivers & 60 \\
\hline RHR heat exchangers & 320 \\
\hline RHR piping system & 100 \\
\hline RHR instrumentation and control & 80 \\
\hline \multicolumn{2}{|l|}{ Reactor core isolation cooling system } \\
\hline RCIC pumps, motors and equipment & 90 \\
\hline RCIC piping system & 100 \\
\hline \multicolumn{2}{|l|}{ High pressure core spray system } \\
\hline HPCS pumps, motors and strainers & 30 \\
\hline HPCS piping system & 100 \\
\hline \multicolumn{2}{|l|}{ Low pressure core spray system } \\
\hline LPCS piping system & 190 \\
\hline \multicolumn{2}{|l|}{ Standby liquid control system } \\
\hline SLCS piping system & 55 \\
\hline \multicolumn{2}{|l|}{ Liquid waste system } \\
\hline \multicolumn{2}{|l|}{ High-purity system } \\
\hline High-purity collection tanks, pumps, motors and equipment & 280 \\
\hline \multicolumn{2}{|l|}{ Low-purity system } \\
\hline Low-purity collection tanks, pumps, motors and equipment & 190 \\
\hline Low-purity waste piping system & 60 \\
\hline \multicolumn{2}{|l|}{ Detergent waste system } \\
\hline Detergent waste tanks, pumps, motors and equipment & 40 \\
\hline Detergent waste filter, demineralizers, $\mathrm{R} / \mathrm{O}$ unit package & 65 \\
\hline \multicolumn{2}{|l|}{ Chemical waste system } \\
\hline Chemical waste tanks, pumps, motors and equipment & 40 \\
\hline \multicolumn{2}{|l|}{ Solid waste system } \\
\hline Dry active waste volume reduction centrifuge, pumps, motors and equipment & 200 \\
\hline Solid waste system piping system & 250 \\
\hline \multicolumn{2}{|l|}{ Fuel handling and storage } \\
\hline \multicolumn{2}{|l|}{ Spent fuel pool cleaning and purification } \\
\hline Pumps, motors, equipment, filters and demineralizers & 400 \\
\hline Spent fuel pool cleaning and purification piping system & 40 \\
\hline \multicolumn{2}{|l|}{ Reactor water cleanup system } \\
\hline RWCU system pumps, motors and heat exchangers & 120 \\
\hline RWCU purification and filter equipment & 80 \\
\hline RWCU piping system & 120 \\
\hline \multicolumn{2}{|l|}{ Auxiliary cooling systems } \\
\hline Plant chilled water system pumps, motors and heat transfer equipment & 80 \\
\hline \multicolumn{2}{|l|}{ Feed water system } \\
\hline Feed ater piping & 70 \\
\hline Feed water valves & 850 \\
\hline \multicolumn{2}{|l|}{ Other turbine plant equipment } \\
\hline Main vapor system piping & 50 \\
\hline Main vapor system valves & 260 \\
\hline Main vapor system instrumentation and control & 100 \\
\hline (Roberson et al., 1984; Beal et al., 1987; White et al., 1984) & \\
\hline
\end{tabular}

\footnotetext{
'Average of across-plant typical values.
} 


\begin{tabular}{|c|c|c|}
\hline & SHUTDOWN & \multirow{2}{*}{$\begin{array}{l}\text { OPERATING } \\
\text { in rem/hr }\end{array}$} \\
\hline & All Volues & \\
\hline (1) & $.025-12.0$ & $.16-14.0$ \\
\hline (2) & $5.1-24.0$ & - \\
\hline 3 & $.025-1.4$ & $\begin{array}{l}r=0.6 \\
n=5-7.7\end{array}$ \\
\hline$(4$ & $.02-.270$ & $2.3-35$ \\
\hline 6 & $5-15$ & $\begin{array}{r}n=394- \\
1300\end{array}$ \\
\hline 6 & 0.1 & .050 \\
\hline 8 & $0.7-200$ & - \\
\hline 8 & $.065-.360$ & $\begin{array}{l}r=2-25 \\
n=2-22\end{array}$ \\
\hline 9 & .065 & .065 \\
\hline (10) & .095 & 5.5 \\
\hline
\end{tabular}
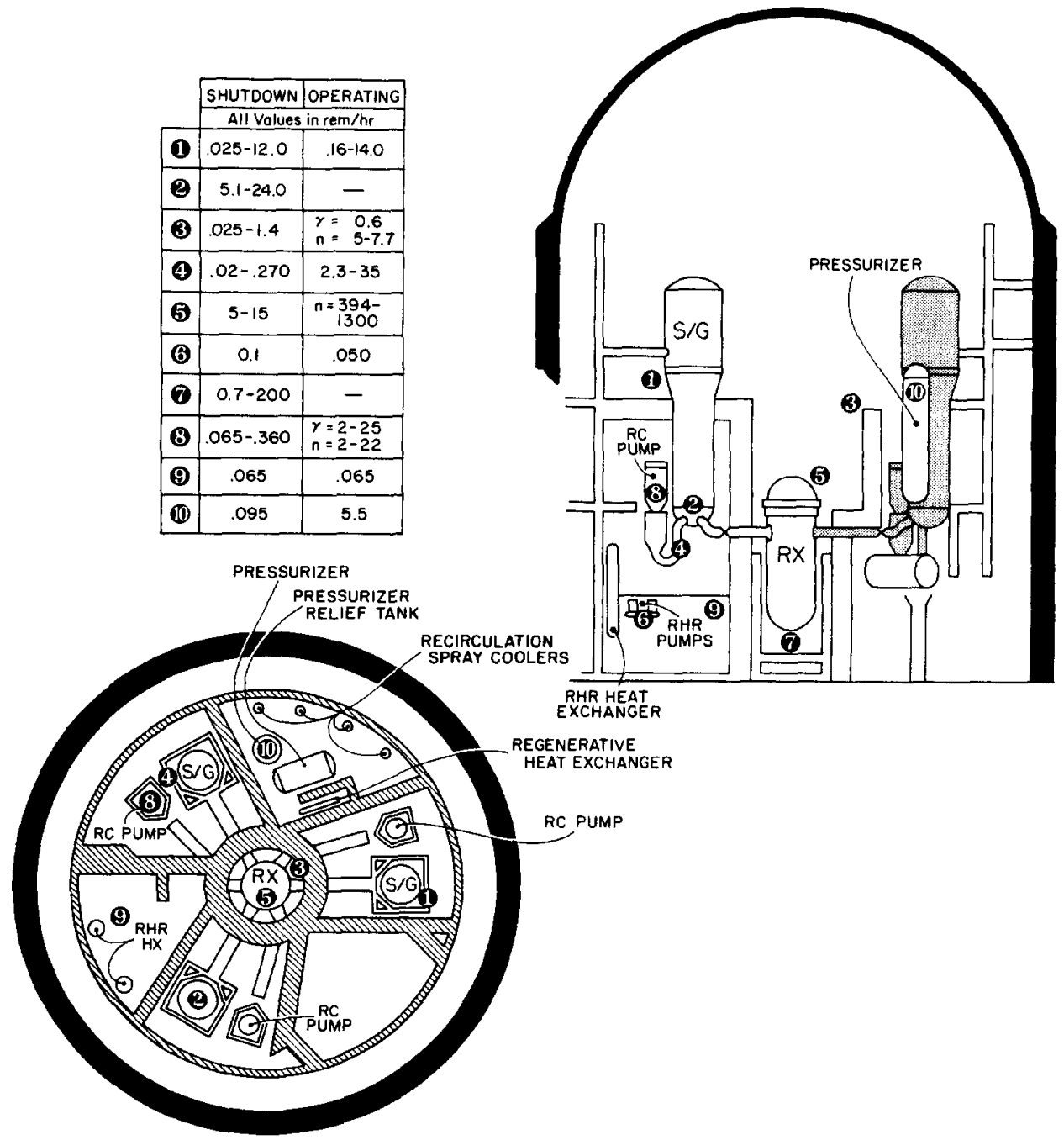

Fig. 1. PWR system/component exposure rates.

are listed in Table $6 .{ }^{60} \mathrm{Co}$ has been found to be the greatest contributor to exposure, and its buildup results from crud deposited near low flow, dead-leg areas and becoming incorporated in corrosion films (Roberson et al., 1984; Anstine, 1983). ${ }^{137} \mathrm{Cs}$ and ${ }^{16} \mathrm{~N}$ have also been found to contribute significantly to exposure (Roberson et al., 1984). The maximum flux of the scattered photon continuum is expected between 50 and $150 \mathrm{keV}$, just above the sharp rise in the photoelectric cross section for atoms in shielding materials. As crud (i.e. the long half-life radioactive deposits) builds with age, the relative contribution of low-energy photons to dose declines (Roberson et al., 1982, 1984). Under normal operating conditions, plantwise average $\gamma$ exposures range from about 0 to $1000 \mathrm{mrem} \mathrm{h}^{-1}$, with an overall average on the order of $10 \mathrm{mrem} \mathrm{h}^{-1}$ (Roberson et al., 1984; White et al., 1984 ; VEPCo, 1979; SMUD, 1975).

\section{NEUTRON EXPOSURE}

For operating reactors it is also important to consider the neutron exposure, especially with respect to potential radiation damage. Using a $\gamma$ detection system to locate high neutron backgrounds is generally not feasible, since away from the vessel there is little correlation between $\gamma$ and neutron exposures, with $\gamma /$ neutron ratios ranging from 0.08 to 100. Usually, only a small percentage of the total radiation exposure is due to neutrons because intense neutron fields are not as prevalent throughout the plant as $\gamma$ fields (Ryan, 1983).

Determining the significant component of the neutron background (i.e. fast, epithermal or slow) is difficult. In some cases only the fast neutrons streaming from the vessel are significant contributors to the exposure (Uhrig, 1977). Sub- 


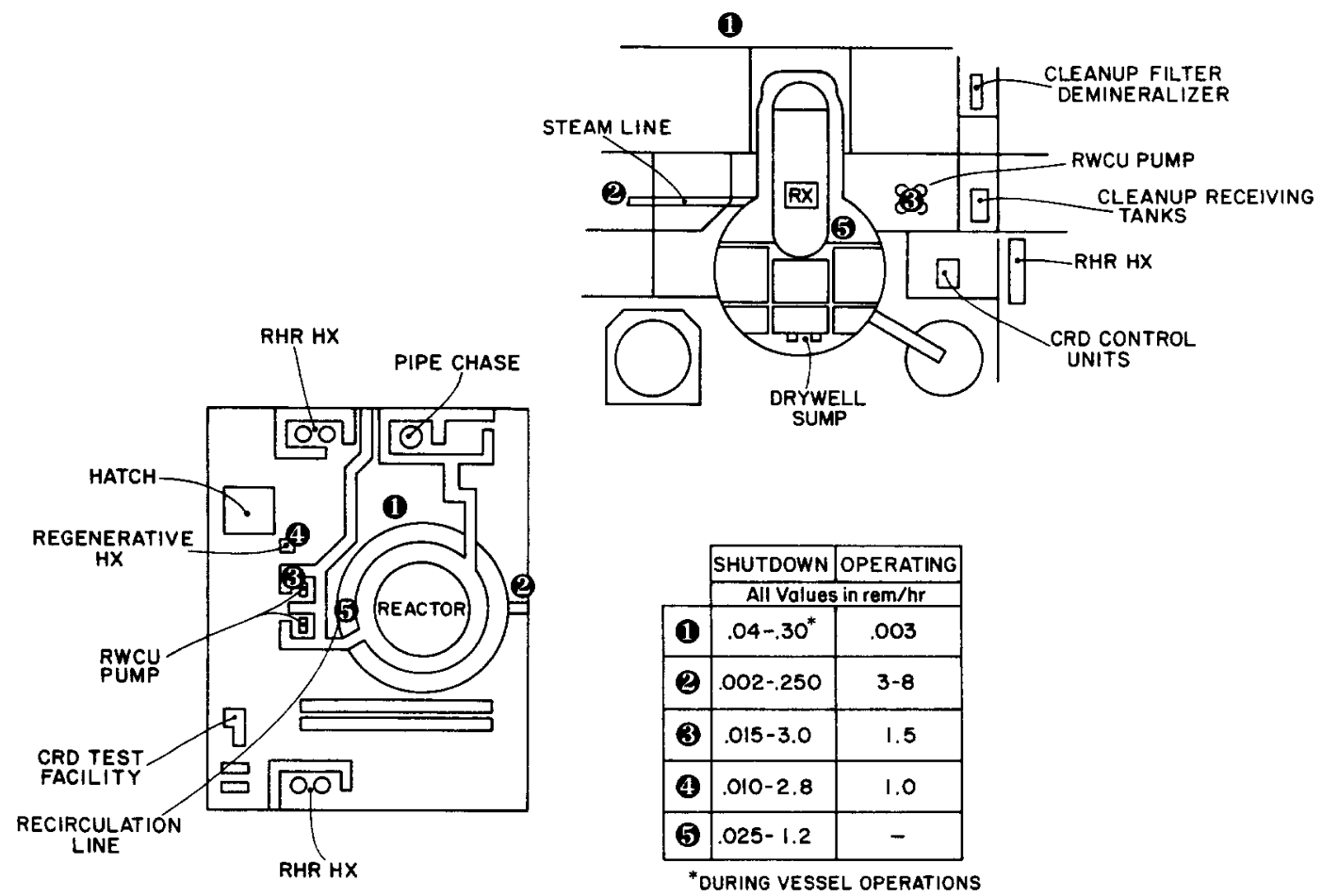

Fig. 2. BWR system/component exposure rates.

stantial neutron leakage from the reactor cavity occurs (Vergnaud et al., 1984):

(1) in the upper part of the reactor pit, in the air gap between the vessel and the biological shield wall, resulting in streaming into the refueling cavity and the operating deck (up to $5 \mathrm{rem} \mathrm{h}^{-1}$ );

(2) around coolant pipes, leading to escape into reactor coolant pump casemates $\left(5-22 \mathrm{rem} \mathrm{h}^{-1}\right)$ and the operating deck above $\left(0.36-2.1 \mathrm{rem} \mathrm{h}^{-1}\right)$;

(3) into the keyways below the vessel;

(4) in the ionization chamber openings on the operating deck (Kosako et al., 1984; Champion et al., 1984) ; and

(5) near the reactor vessel flange gap (Butler et al., 1979).

In most other cases, the contribution of high-energy neutrons to the dose is very small. Average energies are usually less than $100 \mathrm{keV}$ with few neutrons having energies greater than $750 \mathrm{keV}$ (Cummings et al., 1983; Endres et al., 1981) In general, thermal neutrons make up about $40 \%$, epithermal $50 \%$, and fast neutrons $10 \%$ of the total flux spectra (Ryan, 1983 ; Earls and Blok, 1986). Under normal operating conditions away from the vessel, plantwide average neutron exposure rates can be expected to range from $0-1000 \mathrm{mrem}$ $\mathrm{h}^{-1}$, with an overall average on the order of $10 \mathrm{mrem} \mathrm{h}^{-1}$ during operation (Endres et al., 1981; VEPCo, 1979; SMUD, 1975; Walker and Davis, 1977).

\section{ACCIDENT CONDITIONS}

Under abnormal conditions such as an accident, exposures can reach critical levels so quickly that shielding both equip- ment and personnel becomes difficult. Electronic failures at Chernobyl began at $600-800 \mathrm{rad} \mathrm{h}^{-1}$, and the robot used there was completely disabled at $2000 \mathrm{rad} \mathrm{h}^{-1}$ (Tulenko, 1987). Fields reached $10^{5} \mathrm{rad} \mathrm{h}^{-1}$. [A calculation has been performed to simulate a gap release leading to escape of the fission product inventory from the fuel for power plants of U.S. design and similar results of $\sim 10^{4} \mathrm{rad} \mathrm{h}^{-1}$ were obtained (Kenoyer et al., 1982).] Currently, the basement of the TMI plant has a field of $\sim 1200 \mathrm{rad} \mathrm{h}^{-1}$. Locating sources of this magnitude will not be difficult if they are confined to "hot spots", but in the case of a gaseous release, the release will create its own background to the extent that detecting its source will be difficult. Neutron fields will not be the major concern in such accident situations, since the fission product release is thought to produce the more significant hazard.

\section{SUMMARY}

Of the many factors to be accounted for when considering the expected radiation fields to be encountered, several points stand out. Plant $\gamma$ exposure rates were found to typically range from 0 to $1000 \mathrm{mrem} \mathrm{h}^{-1}$, although near the vessel and localized hot spots, substantially larger values exist. Excepting areas such as BWR turbine floors, low-energy scatter photons dominate the spectra during both operating and shutdown conditions. These photons originate mainly from neutron activated corrosion and fission product accumulations, with ${ }^{60} \mathrm{Co}$ being the major contributor to dose. Additional isotopes of concern during operation are ${ }^{16} \mathrm{~N}$ and ${ }^{137} \mathrm{Cs}$. Water chemistry has been shown to be a critical factor 
Table 6. Sources of the photon background energy spectrum

\begin{tabular}{|c|c|c|c|}
\hline \multicolumn{2}{|l|}{ Isotope } & $\gamma$-energy $(\mathrm{keV})$ & $\begin{array}{c}\text { Half-life } \\
\text { (days) }\end{array}$ \\
\hline \multicolumn{4}{|c|}{ Neutron activated } \\
\hline $\mathrm{Sb}$ & 124 & $602.7,722.8,1691$ & 60.2 \\
\hline $\mathrm{Ar}$ & 41 & 1294 & 0.0763 \\
\hline $\mathrm{C}$ & 15 & 5298 & $2.83 \times 10^{-5}$ \\
\hline \multirow[t]{2}{*}{$\mathrm{Co}$} & 58 & 810.8 & 70.91 \\
\hline & 60 & 1173,1332 & 1924 \\
\hline $\mathrm{Cr}$ & 51 & 320.1 & 27.70 \\
\hline $\mathrm{D}$ & $(\mathrm{n}, \gamma)$ & 2200 & \\
\hline $\mathrm{Fe}$ & $\begin{array}{l}59 \\
(\mathrm{n}, \gamma)\end{array}$ & $\begin{array}{l}1099,1292 \\
4200,5900,6000,7300,7600\end{array}$ & 44.51 \\
\hline $\mathrm{Mn}$ & 54 & $\begin{array}{l}834.8 \\
846.8\end{array}$ & $\begin{array}{l}312.2 \\
0.1075\end{array}$ \\
\hline Mo & $\begin{array}{l}99 \\
101\end{array}$ & $\begin{array}{l}140.5,739.6 \\
192.0,505.9,9.590 .9,1013\end{array}$ & $\begin{array}{l}2.748 \\
0.01014\end{array}$ \\
\hline $\mathrm{Ni}$ & 65 & 1482,1116 & 0.1050 \\
\hline $\mathrm{N}$ & 16 & 6129,7115 & $8.25 \times 10^{-5}$ \\
\hline Sn & $\begin{array}{l}113 \\
125 \mathrm{~m}\end{array}$ & $\begin{array}{l}391.7 \\
332.0\end{array}$ & $\begin{array}{l}115.1 \\
6.61 \times 10^{-3}\end{array}$ \\
\hline $\mathrm{Xe}$ & $\begin{array}{l}133 \\
135\end{array}$ & $\begin{array}{l}81.00 \\
249.8\end{array}$ & $\begin{array}{l}5.25 \\
0.379\end{array}$ \\
\hline $\mathrm{Zn}$ & 65 & 1116 & 243.8 \\
\hline $\mathrm{Zr} / \mathrm{Nb}$ & 95 & $\begin{array}{l}756.7,724.2,235.7,7.778 .2 \\
568.9,1091\end{array}$ & 64.03 \\
\hline \multicolumn{4}{|c|}{ Other: } \\
\hline \multicolumn{2}{|c|}{$\begin{array}{l}\text { Annihilation } \\
\text { Lead X-rays }\end{array}$} & $\begin{array}{l}511 \\
\sim 200\end{array}$ & \\
\hline \multicolumn{4}{|c|}{$\begin{array}{l}\text { (Roberson et al., 1984; Berry and Diegle, 1979) } \\
\text { Fission }\end{array}$} \\
\hline Cs & $\begin{array}{l}134 \\
137\end{array}$ & $\begin{array}{l}604.7,795.8 \\
661.7\end{array}$ & $\begin{array}{l}753.7 \\
11,010\end{array}$ \\
\hline I & $\begin{array}{l}131 \\
132 \\
133 \\
134 \\
135 \\
136\end{array}$ & $\begin{array}{l}364.5 \\
667.7,772.6 \\
529.9 \\
847.0,884.1 \\
1260,1132,526.6 \\
1313,1321\end{array}$ & $\begin{array}{l}8.040 \\
0.950 \\
0.867 \\
0.365 \\
0.2744 \\
9.68 \times 10^{-4}\end{array}$ \\
\hline $\mathrm{Kr}$ & $\begin{array}{l}83 \mathrm{~m} \\
85 \mathrm{~m} \\
85 \\
87 \\
88 \\
89 \\
90\end{array}$ & $\begin{array}{l}9.39 \\
151.2 \\
514 \\
402.6 \\
2392,196.3 \\
220.9,585.8 \\
1119,1218,5395\end{array}$ & $\begin{array}{l}0.0775 \\
0.187 \\
3913 \\
0.053 \\
0.118 \\
0.00219 \\
3.74 \times 10^{-4}\end{array}$ \\
\hline $\mathrm{Sr}$ & 89 & 909.2 & 50.52 \\
\hline \multirow[t]{2}{*}{$\mathrm{Xe}$} & $\begin{array}{l}133 \\
135 \mathrm{~m} \\
135 \\
137 \\
138 \\
139\end{array}$ & $\begin{array}{l}81.00 \\
768.9 \\
249.8 \\
455.5 \\
258.4,434.5,1768,2016 \\
218.6,296.5,174.9\end{array}$ & $\begin{array}{l}5.25 \\
0.0106 \\
0.379 \\
0.00267 \\
0.00979 \\
4.6 \times 10^{-4}\end{array}$ \\
\hline & & (Pigford, 1972) & \\
\hline
\end{tabular}

in overall plant exposure rates. The exposure rates tend to level off after $\sim 1$ yr in PWRs and $\sim 4$ yr in BWRs, although for steam generators (a significant contributor to exposure in PWRs) and on BWR recirculation piping systems and turbine floors, the fields level off after $\sim 5 \mathrm{yr}$. Away from the vessel, neutrons are generally not significant contributors to total doses, and no correlation appears to exist between $\gamma$ and neutron doses.
The specific values presented here are meant to provide rough estimates of the expected field strengths found in shutdown and operating BWRs and PWRs. In order to be useful for shielding purposes, in certain cases the values presented may be conservatively high. Nevertheless, the data presented here represent the best estimates to date. In order to form a more comprehensive database on operating plants, those having additional information are encouraged to respond directly to the authors.

\section{REFERENCES}

Anstine L. D. (1983) Report EPRI-NP-3114-SY, Electric Power Research Institute.

Beal S. K., Britz S. C., Cohen S. C., Goldin A. S. and Goldin D. J. (1987) Report NUREG/CR-5035, U.S. Nuclear Regulatory Commission.

Berry W. E. and Diegle R. B. (1979) Report EPRI-NP-522, Electric Power Reserch Institute.

Bradshaw R. W. (1987) Report EPRI-NP-4998, Electric Power Research Institute.

Burg R. J., Flynn J. J., Gregg B. R. and Nilsen R. (1980) Report DOE/ET 34004-1.

Butler H. M., Ohnsorge W. F. and Auxier J. A. (1979) Trans. Am. Nucl. Soc. 30, 611

Champion G., Bevilacqua A., Lloret R., Mourgues M. and Vergnaud T. (1984) Proc. Am. Nucl. Soc. Top. Mtg Reactor Phys Shielding, p. 448.

Cummings F. M., Endres G. W. R. and Brackenbush L. W. (1983) Reports NUREG/CR-1769 and PNL-4471, U.S. Nuclear Regulatory Commission.

Earls C. E. and Blok J. (1986) Report EPRI-NP-4823, Electric Power Research Institute.

Endres G. W. R., Aldrich J. M., Brackenbush L. G., Gaust L. G., Griffith R. V. and Hankins D. E. (1981) Reports NUREG/CR-1769 and PNL-3585, U.S. Nuclear Regulatory Commission.

Kenoyer J. C., Pickett B. D. and Desrosiers A. E. (1982) Trans. Am. Nucl. Soc. 43, 618.

Kosako T., Matsumoto J., Sekisuchi A., Tabeda S. and Takita T. (1984) Proc. Am. Nucl. Soc. Top. Mtg Reactor Phys Shielding, p. 472.

Palino G. F., Hobart R. L. and Sawochka S. G. (1987) Report EPRI-NP-5455, Electric Power Research Institute.

Pigford T. (1972) IEEE Trans Nucl. Sci. 19, 15.

Rathbun L. A. and Endres G. W. R. (1983) Reports NUREG/CR-2893 and PNL-4395, Pacific Northwest Laboratories.

Roberson P. L., Endres G. W. R., Fox R. A., Haggard D. L., Holbrook K. L. and Rathbun L. A. (1982) Report PNL-SA-10743, Pacific Northwest Laboratories.

Roberson P. L., Endres G. W. R., Fox R. A., Haggard D. L., Holbrook K. L. and Rathbun L. A. (1984) Reports NUREG/CR-3569 and PNL-4915, U.S. Nuclear Regulatory Commission.

Ryan, R. M. (1983) Report NUREG/CR-2524, U.S. Nuclear Regulatory Commission.

Scaglia L. A. and Bergmann C. A. (1987) Report EPRI-NP5234, Electric Power Research Institute.

Sejvar J., Crotzer M. E. and Frank F. J. (1981) Report EPRINP-858, Electric Power Research Institute.

SMUD (Sacramento Municipal Utility District) (1975) Rancho Seco Startup Report.

Tulenko J. S. (1987) University of Florida Monthly Report. 
A Remote Telepresence Robotic System for Inspection and Maintenance of Nuclear Power Plants (unpublished).

Uhrig, R. E. (1977) St Lucie unit 1 Startup Physics Testing Report to the U.S. Nuclear Regulatory Commission.

Vance, J., Waver C. L. and Lepper E. M. (1978) Atomic Industrial Forum Report on The Potential Impacts on Operating Nuclear Power Plants of a 500 MREM/YEAR Occupational Exposure Limit.

VEPCo (Virginia Electric Power Co) (1979) North Anna Startup Report.

Vergnaud T., Bourdet L., Champion G. and Nimal J. C,
(1984) Neutron dose rate in the upper part of a PWR containment-comparison between measurements and TRIPOLI-2 calculations. Proc. Am. Nucl. Soc. Top. Mig Reactor Phys Shielding.

Walker R. E. and Davis D. K. (1977) St Lucie Unit 1 Neutron Streaming Report to the U.S. Nuclear Regulatory Commission.

White J. R., Eversole R. E., Farnstrom K. A., Harvey H. W. and Martin H. L. (1984) Report NUREG/CR-3717, U.S. Nuclear Regulatory Commission. 